\author{
Janusz PORZYCKI ${ }^{1}$ \\ Roman WDOWIK ${ }^{2}$ \\ Marek KROK ${ }^{3}$
}

\title{
THE GRINDING WHEELS FOR ULTRASONIC AS- SISTED GRINDING WITH TOOL VIBRATION
}

\begin{abstract}
This article presents the grinding tools designed to serve hybrid machining process - ultrasonic wheel vibration assisted grinding. It describes possibilities of using of different abrasives, grinding wheel clamping systems and holders with ultrasonic oscillation inductor. Realization of Ultrasonic Assisted Grinding (UAG) process is possible on machines with special design. Most machine tools are manufactured on the basis of conventional ones and are retrofitted with ultrasonic vibration system. There are two types of tool holders designed for this machine tool: holders for hybrid machining processes (ultrasonic actors) and holders for conventional processes. Each type of tool holder is fixed to the spindle with hollow taper shank. The tools are attached to the ultrasonic actors by screw and positioned on arbor, or by the collets. For the UAG process tools made of various abrasives are applicable. Binding material, the concentration of abrasive grains and their size may differ. It is possible to use diamond or cubic boron nitride tools and also tools made of conventional abrasives. Ultrasonic Assisted Grinding is a novelty in the field of manufacturing techniques. It is necessary to conduct detailed investigations of this process. The factors that have a significant impact on the UAG results for different materials, the oscillatory motion parameters in relation tool or workpiece as well as on the dressing tool should be investigated.
\end{abstract}

Keywords: grinding, ultrasonic assisted grinding, UAG, tools for UAG,

\section{Introduction}

With the development of constructing materials it is necessary to develop new methods for their machining. This is due primarily inability to obtain specific properties of these materials by using of conventional machining processes and tools. Effective machining of materials difficult to workable often requires

\footnotetext{
${ }^{1}$ Autor do korespondencji/corresponding author: Janusz Porzycki, Rzeszow University of Technology, 2 W. Pola Street, 35-959 Rzeszow, tel.: (17) 8651347, e-mail: jpor@ prz.edu.pl

${ }^{2}$ Roman Wdowik, Rzeszow University of Technology, 2 W. Pola Street, 35-959 Rzeszow, e-mail: rwdowik@prz.edu.pl

${ }^{3}$ Marek Krok, Rzeszow University of Technology, 2 W. Pola Street, 35-959 Rzeszow, e-mail mkrok@prz.edu.pl
} 
the usage of hybrid machining processes. According to the definition, these processes are based on the simultaneous and controlled interaction between mechanical process and/or energy/tools having a significant impact on the efficiency of the machining process [1]. Hybrid machining processes are part of the more commonly used hybrid production which includes also hybrid machines, hybrid products, hybrid materials, etc. Division of hybrid processes oriented for removal machining is presented on Fig. 1. One of the most commonly used hybrid machining process is tools or workpiece oscillations assisted machining (VAM - Vibration Assisted Machining). If the frequency of oscillation is greater than $16 \mathrm{kHz}$, and therefore the frequency is within the range of ultrasound, this type of machining is called UAM - Ultrasonic Assisted Machining, for example UAT - Ultrasonic Assisted Turning or UAG - Ultrasonic Assisted Grinding. Kinematics of these processes covers conventional process and assisting factor in the form of oscillatory tool or machining workpiece with a small amplitude and frequency of the ultrasonic, a small amplitude and frequency of the ultrasonic resulting from the reverse piezoelectric effect or magnetostriction. Of particular note is the process of ultrasonic assisted grinding which is applying to the machining of hard, ductile and brittle materials, for example technical ceramic, sintered carbide, quartz [1-9], and also different constructing material as steel [10-12], nickel alloys [13,14] or titan alloys [4, 1518]. There are two main types of such process: ultrasonic assisted grinding with tool oscillation and ultrasonic assisted grinding with workpiece oscillation. Division of each kind takes into account the direction of oscillation in relation to other movements of the workpiece and tool (Fig. 2). To the process of UAG may be used grinding wheels made of different abrasives, depending on the intended machining task.

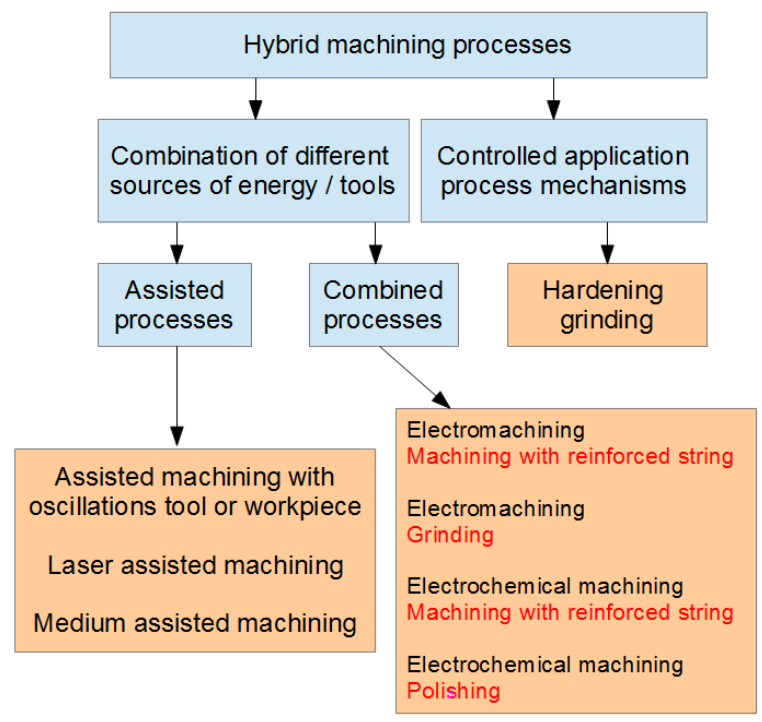

Fig. 1. Division of hybrid machining processes 

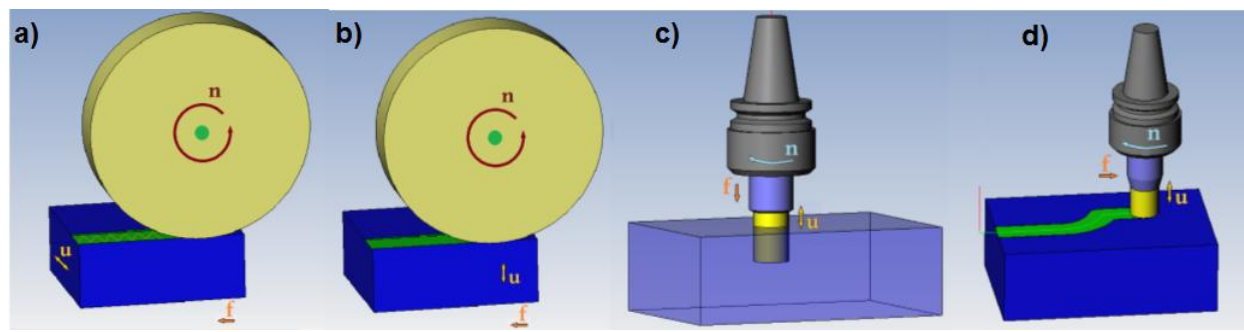

Fig. 2. The basic kinds of UAG process: a) grinding with axial oscillations of the workpiece, b) grinding with radial oscillations of the workpiece, c), d) grinding with tool oscillations

Realization of ultrasonic assisted process is possible on machines with special design. Most machines are manufactured on the basis of conventional retrofitted with ultrasonic oscillations system. The well-known manufacturers of such machines are: Sauer from Germany and SonicMill from the United States of America. At the Technical University of Rzeszów there is a machine produced by Sauer with the ultrasonic oscillations induction system of grinding wheel Ultrasonic 20 linear. This hybrid machining center built on the basis of 5-axis milling machine is used for milling, drilling and grinding assisted ultrasonic oscillations of tool (Fig. 3). The advantages of this machine are: linear motor drives for all linear axis, making it possible to achieve a feed rate of up to 40,000 $\mathrm{mm} / \mathrm{min}, 5$ axis kinematics with swivelling rotary table, which leads to increase the technological capabilities, 20-position tool magazine, spindle allowing working at a rotational speed up to $40,000 \mathrm{rev} / \mathrm{min}$ and the oscillation inducing system requires the usage of special tool holders.

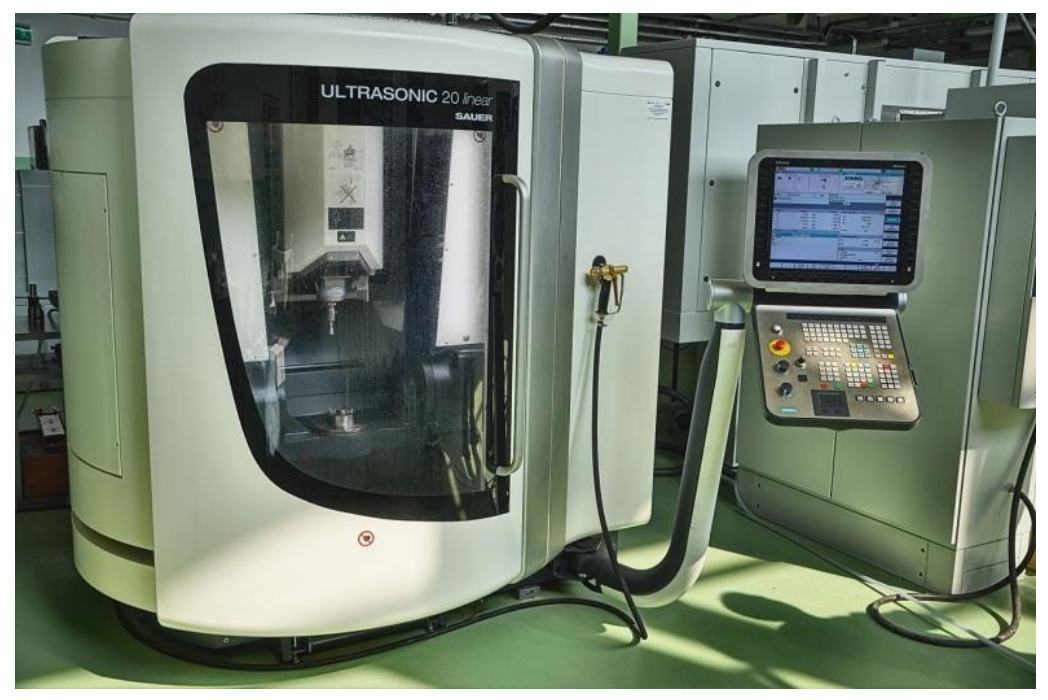

Fig. 3. CNC machining centre ULTRASONIC 20 linear 
One of the main objectives of the research work carried out at the Department of Manufacturing Techniques and Automation at the Rzeszow University of Technology in the field of ultrasonic-assisted grinding is analysis of oscillating tools motion, analysis of quality rating of UAG, the possibilities for using different materials and different tool geometry as well as the construction of the oscillation inducing systems and machines for the implementation of the described processes.

\section{Tools and tool holders for UAG process}

Applicable tooling system designed for the machine Ultrasonic 20 linear can be divided into holders for hybrid processes (Fig. 4a) and the holders for conventional processes (Fig. 4b). Each type of tool holder is fixed to the spindle with hollow taper shank (taper type is HSK 32). The fundamental difference in the construction is that the holder to the hybrid processes (UA - Ultrasonic actors) has a coil located directly at the cone HSK which together with the coil installed on the body of the machine tool spindle is designed to transfer electrical energy and its conversion into mechanical vibrations in piezoelectric converters located in the center of the tool holder. Machining tools are attached to the UA holders by bolt and positioned on arbor (e.g. cup wheels 6A9) or by the collet ER-11. For the second case tool clamping can be carried out with the usage of reducing collet (tools with cylindrical shank) or directly in the case of grinding wheels with conical shank. Tools should be fixed using a torque wrench (control mounting torque) due to the impact into the adjustable process parameters (frequency of oscillation, the oscillation amplitude).

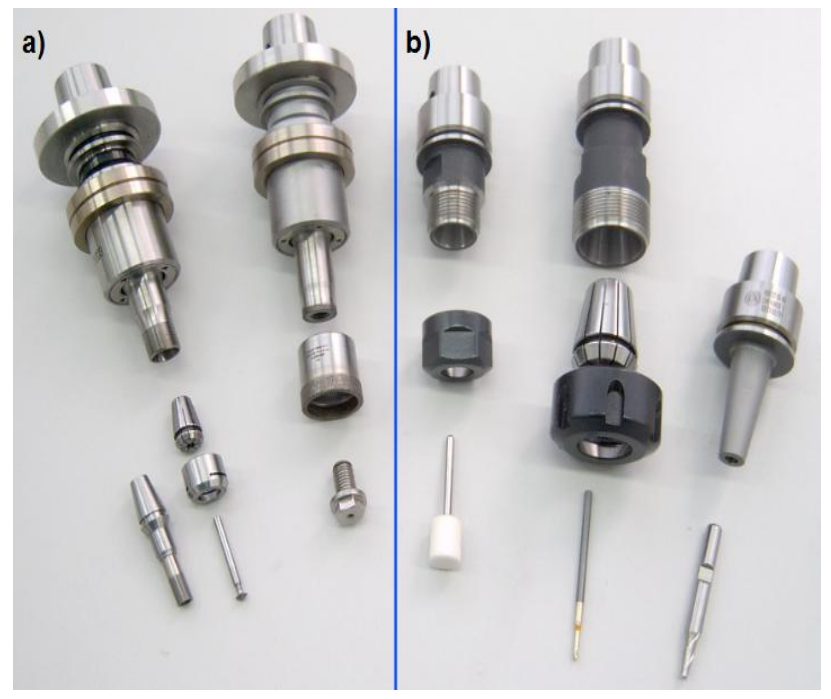

Fig. 4. Tool holders with hollow taper HSK 32: a) for hybrid processes, b) for conventional processes 
The dimensions of grinding wheel are also important due to the requirements for settings resonance frequency of the system (for which the amplitude of the displacement is greatest), and included in the settings wheel wear that also affects the resonant frequency. While selecting grinding pin mounting by using collet reduction should pay particular attention to the quality of the shank (due to the radial run-out) which should be sanded and with small deviations of shape. Fixing of a tool is also affected by quality of reduction collet. UA holders should not also be exposed to sudden mechanical shock. Holder fixing mechanism in the spindle must be checked periodically because of the type of mounting taper HSK, in order to prevent jamming holder in the spindle. For the UAG process tools made of various abrasives are applicable. Tools also vary in binding material, the concentration of abrasive grains and their size. It is possible to use grinding pin made of CBN (Fig. 5a), diamond (Fig. 5b, c, d), alundum, silicon carbide and sintering corundum.
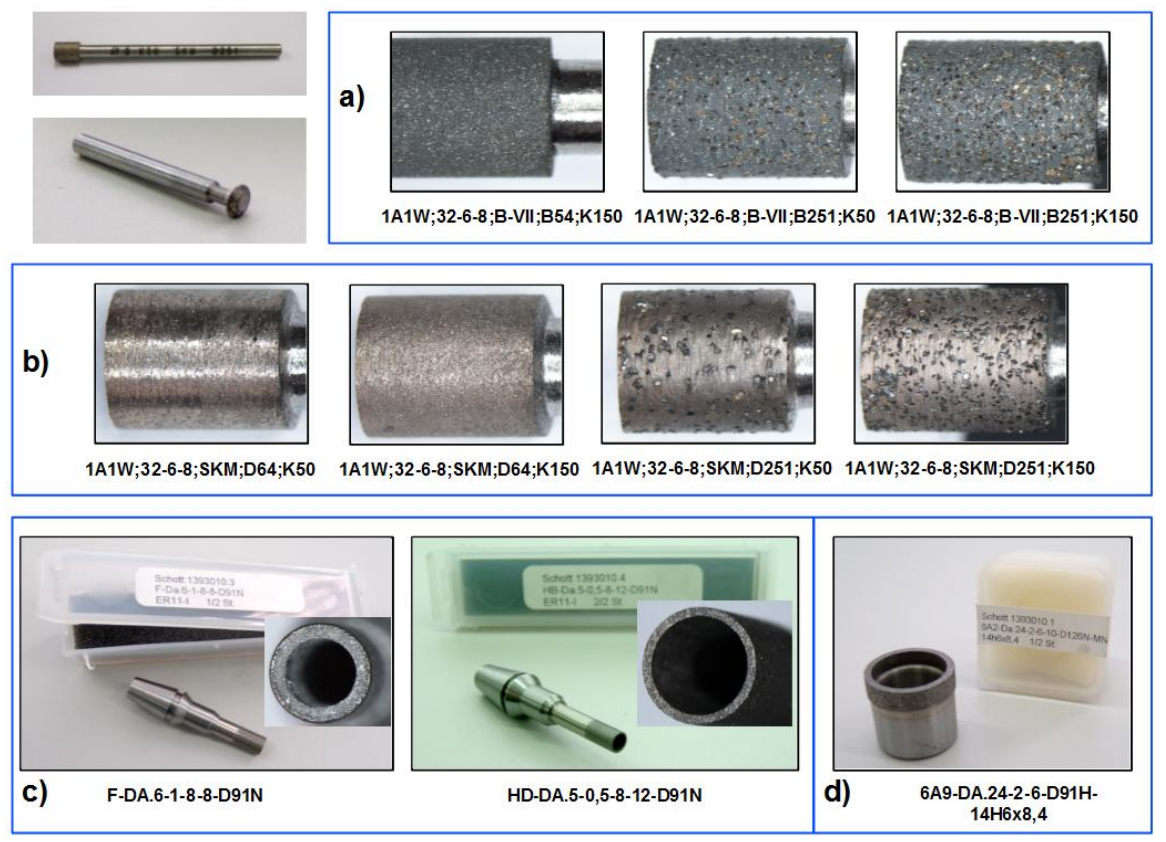

Fig. 5. Examples of tools used in UAG process with tool oscillations: a) grinding pin made of $\mathrm{CBN}, \mathrm{b}$ ) grinding pin made of diamond, c) wheels to cut-leading grinding and drilling, d) diamond cup wheels mounted on the shank shaft

\section{Estimation of grinding wheel wear in the UAG process}

Wheel wear in the UAG is considered as a change of its shape, the loss of grinding wheel, adhesive wear and gumming up of grinding wheels. Any form of the wheel wear requires the use of appropriate research methods aimed at 
understanding quality and quantitative indicators of grinding wear (Fig. 6). Rating shape of the wheel is based on microscopic examination and testing on CNC edge finder where a magnified wheel profile can be observed. The loss of grinding wheel shape can be determined by using of CNC edge finder based on a comparison of the wheel profile before and after the process or by comparing the virtual models created on CNC edge finder. Adhesive wear is mainly investigated by using of optical microscope, as well as gumming up of grinding wheels. In the research institutes there are also ongoing studies on the processes of dressing the grinding wheel by using ultrasonic vibrations. These results may be critical to increase the efficiency of dressing grinding wheels, particularly with regard to their impact on the processes of grinding of materials difficult to machine [19].
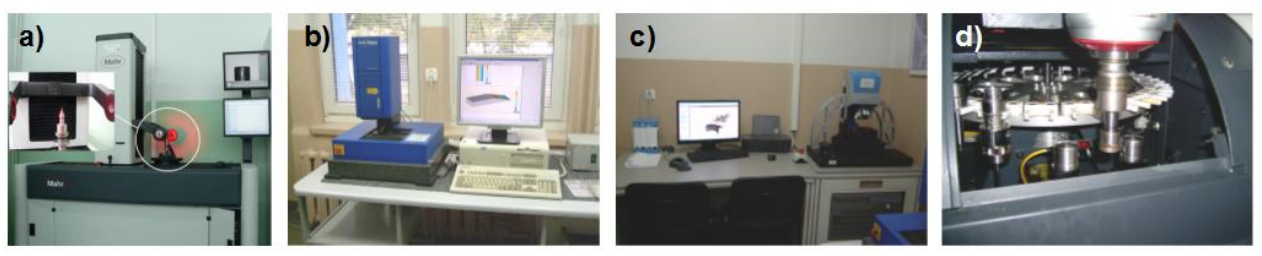

Fig. 6. Examples of test methods used for measurement wheel wear: a) measurement on CNC edge finder, b) measurement of wheel inner radius on 3D surface scanner, c) measurement of wheel inner radius on InfiniteFocus Real 3D microscope, d) measurement on laser gate installed on the machine Ultrasonic 20 linear

\section{Summary}

Ultrasonic Assisted Grinding of hard-to-machine materials is a novelty in the field of manufacturing techniques from these materials. It is necessary to conduct research accounting a detailed look at the factors that have a significant impact on the quality of UAG indicators, the oscillatory motion parameters such as amplitude and frequency of the motion in relation to vibration tool or workpiece as well as in the dressing tool. It is also essential to testing materials with different mechanical properties. In the Department of Manufacturing Techniques and Automation there are intensive researches that will lead to better understanding of the ultrasonic assisted machining processes. The proper choice of the abrasive tools (grinding characteristics, method of fixing) is one of the areas of the research. Appropriate selection of the wheel is important for the proper conduct of oscillatory motion. This mean that certain parameters oscillatory motion can be reached and negative events reduced, for example thermal phenomena associated with heating holder with the tool, disrupting the immutability of the parameters such as the amplitude of the oscillations measured directional in tool axis. 


\section{References}

[1] Lauwers B., Bleicher F., Ten Haaf P., Vanparys M., Bernreiter J., Jacobs T., Loenders J.: Investigation of the process-material interaction in ultrasonic assisted grinding of $\mathrm{ZrO} 2$ based ceramic materials, Proc. of 4th CIRP Int. Conf. High Performance Cutting, 2010.

[2] Churi N.: Rotary ultrasonic machining of hard-to-machine materials, Diss., Kansas State University, Manhattan, Kansas 2010.

[3] Marinescu I.D., Hitchiner M., Uhlmann E., Rowe W.B., Inasaki I.: Handbook of machining with grinding wheels, CRC Press, Taylor and Francis Group, USA 2007.

[4] Qin N.: Modeling and experimental investigation on ultrasonic-vibration-assisted grinding, Diss., Kansas State University, Manhattan, Kansas 2011.

[5] Rowe B.W.: Principles of modern grinding technology, William Andrew, London 2009.

[6] Spur G., Uhlmann E., Holl S.-E., Daus N.-A.: Ultrasonic machining of ceramics, [in:] Handbook of Advanced Ceramics Machining, ed. by I.D. Marinescu, CRC Press Taylor \& Francis Group, 2007, 327-353.

[7] Uhlmann E., Submitted by Spur G.: Surface formation in creep feed grinding of advanced ceramics with and without ultrasonic assistance, Annals CIRP, 47 (1998), 249-252.

[8] Uhlmann E.G.: Tiefschleifen hochfester keramischer Werkstoffe, Diss., Berlin 1993.

[9] Ultrasonic Assisted Grinding of Brittle Hard Materials - UAG - rep. of CORNET project.

[10] Smail M.F., Yanagi K., Isobe H.: Geometrical transcription of diamond electroplated tool in ultrasonic vibration assisted grinding of steel, Int. J. Mach. Tools Manuf., 62 (2012), 24-31.

[11] Tawakoli T., Azarhoushang B.: Influence of ultrasonic vibrations on dry grinding of soft steel, Int. J. Mach. Tools Manuf., 48 (2008), 1585-1591.

[12] Tawakoli T., Azarhoushang B., Rabiey M.: Ultrasonic assisted dry grinding of 42CrMo4, Int. J. Adv. Manuf. Technol., 65 (2009), 883-891.

[13] Abdullah A., Farhadi A., Pak A.: Ultrasonic-assisted dry dreep-feed up-grinding of superalloy Inconel 738LC, Experimental Mechanics (12.10.2011).

[14] Bhaduri D., Soo S.L., Aspinwall D.K., Novovic D., Harden P., Bohr S., Martin D.: A study on ultrasonic assisted creep feed grinding of nickel based superalloys, 5th CIRP Conference on High Performance Cutting, 2012.

[15] Kumar J., Khamba J.S., Mohapatra S.K.: An investigation into machining characteristics of titanium using ultrasonic machining. Int. J. Mach. Machinability Mat., 3 (2008), 134-151.

[16] Nik M.G., Movahhedy M.R., Akbari J.: Ultrasonic-assisted grinding of Ti6Al4V alloy, 5th CIRP Conf. High Performance Cutting, 2012.

[17] Singh R., Khamba J.S.: Ultrasonic machining of titanium and its alloys: A review, J. Mat. Proc. Technol., 173 (2006), 125-135. 
[18] Singh R., Khamba J.S.: Investigation for ultrasonic machining of titanium and its alloys, J. Mat. Proc. Technol., 183 (2007), 363-367.

[19] Tawakoli T., Rasifard A., Azarhoushang B.: Dressing of CBN grinding wheels with ultrasonic assistance, Int. J. Mechatronics Manuf. Systems, 1 (2008), 321-331.

\section{NARZĘDZIA ŚCIERNE PRZEZNACZONE DO REALIZACJI PROCESU SZLIFOWANIA WSPOMAGANEGO ULTRADŹWIĘKOWYMI OSCYLACJAMI ŚCIERNICY}

\section{Streszczenie}

W pracy przedstawiono narzędzia ścierne przeznaczone do realizacji hybrydowego procesu obróbki ubytkowej - szlifowania wspomaganego drganiami ultradźwiękowymi ściernicy. Omówione zostały możliwości w zakresie stosowania różnych materiałów ściernych oraz systemów mocowania ściernic w oprawkach ze wzbudnikiem oscylacji ultradźwiękowych. Praca prezentuje narzędzia szlifierskie przeznaczone do obsługi hybrydowego procesu obróbki - szlifowania ze wspomaganiem ultradźwiękowym i oscylacyjnym narzędziem. Opisuje możliwości wykorzystania równych materiałów ściernych, systemy mocowania tarcz ściernych i dociskaczy ze wzbudnikiem indukcyjnym. Realizacja procesu szlifowania wspomaganego ultradźwiękowo jest możliwa na maszynach o specjalnej budowie. Większość narzędzi maszynowych jest produkowana konwencjonalnie i modernizowana w system wibracji ultradźwiękowych. Istnieją dwa rodzaje oprawek narzędziowych: oprawki do hybrydowej obróbki skrawaniem (ultradźwiękowe) oraz oprawki do procesów konwencjonalnych. Każdy typ oprawki narzędziowej jest przymocowany do wrzeciona z wydrążonym trzpieniem stożkowym. Narzędzia te są mocowane za pomocą śrub i umieszczane w oprawce lub tulei zaciskowej. W procesie szlifowania wspomaganego ultradźwiękami zastosowania mają różne materiały ścierne. Stosowane są różne materiały wiążące oraz różne koncentracje i wielkości ziarn ściernicy. Możliwe jest zastosowanie jako narzędzia diamentu lub regularnego azotku boru. Szlifowanie wspomagane ultradźwiękami jest nowością w dziedzinie technik wytwarzania. Konieczne jest przeprowadzenie szczegółowych badań tego procesu. Należy zbadać czynniki, które wywierają istotny wpływ na wyniki procesu szlifowania wspomaganego ultradźwiękami podczas obróbki różnych materiałów na parametry ruchu oscylacyjnego narzędzia w stosunku do przedmiotu obrabianego oraz na obciagacz.

Słowa kluczowe: szlifowanie, obróbka wspomagana ultradźwiękami, UAG, narzędzia do UAG

DOI:10.7862/rm.2013.16

Otrzymano/received: 24.05 .2013

Zaakceptowano/accepted: 25.06 .2013 